\title{
HUBUNGAN ANTARA DISIPLIN KERJA, LINGKUNGAN KERJA DAN ETOS KERJA DENGAN PRODUKTIVITAS KERJA PERAWAT DI RUANG RAWAT INAP RS PERTAMINA BINTANG AMIN BANDAR LAMPUNG TAHUN 2018
}

\author{
Nopi Sani ${ }^{1}$
}

${ }^{1}$ Departemen Biokimia, Fakultas Kedokteran, Universitas Malahayati

\begin{abstract}
Relationship Between Working Discipline, Work Environment And Work Ethos With Nursing Productivity In The Inpatient Hospital Of Pertamina Bintang Amin Bandar Lampung Hospital, 2018. Human resources management is needed to improve the ability of the employees to provide quality health services. Nurse is one of the important elements in the process of health care, especially in providing nursing care to the patients. One of the benchmarks in assessing the quality of nursing services in hospitals is the assessment of the quality of nursing services in the inpatient room. There are many factors that can increase nurse work productivity including work discipline, work environment and work ethic. The purpose of this study is to determine the relationship of work discipline, work environment and work ethic with the working productivity of the nurses in the inpatient room of Pertamina Bintang Amin Hospital Bandar Lampung in 2018. There were 104 respondents who met the inclusion and exclusion criteria by using simple random sampling technique. The data were analyzed by univariate and bivariate (Chi-Square). Univariate analysis showed diverse respondent characteristics and good work productivity (78.8\%). There was a relationship between work discipline, work environment, and work ethic with work productivity.
\end{abstract}

Keywords: productivity, work ethic, nurses, work discipline, work environment

\begin{abstract}
Abstrak: Hubungan Antara Disiplin Kerja, Lingkungan Kerja Dan Etos Kerja Dengan Produktivitas Kerja Perawat Di Ruang Rawat Inap Rs Pertamina Bintang Amin Bandar Lampung Tahun 2018. Manajemen sumber daya manusia diperlukan untuk meningkatkan kemampuan karyawan dalam memberikan pelayanan kesehatan yang berkualitas. Perawat merupakan salah satu unsur penting dalam proses pelayanan kesehatan khususnya dalam pemberian asuhan keperawatan kepada pasien. Salah satu tolak ukur dalam penilaian mutu pelayanan keperawatan di rumah sakit adalah dengan menilai mutu pelayanan keperawatan yang ada di ruangan rawat inap. Banyak faktor yang dapat meningkatkan produktivitas kerja perawat diantaranya adalah disiplin kerja, lingkungan kerja dan etos kerja. Tujuan penelitian ini mengetahui hubungan disiplin kerja, lingkungan kerja dan etos kerja dengan produktivitas kerja perawat di ruang rawat inap RS Pertamina Bintang Amin Bandar Lampung tahun 2018. Responden berjumlah 104 responden yang memenuhi kriteria inklusi dan eksklusi dengan teknik pengambilan simple random sampling. Data dianalisis dengan univariat dan bivariat (ChiSquare). Analisis univariat menunjukkan karakteristik responden yang beragam dan produktivitas kerja yang baik $(78,8 \%)$. Terdapat hubungan antara disiplin kerja, lingkungan kerja, dan etos kerja dengan produktivitas kerja.
\end{abstract}

Kata Kunci : Produktivitas, etos kerja, perawat, disiplin kerja, lingkungan kerja

PENDAHULUAN

Menurut Peraturan Menteri

Kesehatan Nomor 56 Tahun 2014

tentang Klasifikasi dan Perizinan Rumah

Sakit, rumah sakit adalah institusi pelayanan kesehatan yang menyelenggarakan pelayanan kesehatan perorangan secara paripurna yang menyediakan pelayanan rawat inap, rawat jalan, dan gawat darurat. 
Perawat merupakan salah satu unsur penting dalam proses pelayanan kesehatan khususnya dalam pemberian asuhan keperawatan kepada pasien. Hal ini terkait dengan keberadaan perawat yang bertugas selama 24 jam melayani pasien, serta jumlah perawat yang mendominasi tenaga kesehatan di rumah sakit. Salah satu tolak ukur dalam penilaian mutu pelayanan keperawatan di rumah sakit adalah dengan menilai mutu pelayanan keperawatan yang ada di ruangan rawat inap. Banyak faktor yang dapat meningkatkan produktivitas kerja perawat diantaranya adalah disiplin kerja, lingkungan kerja, etos kerja dan kesempatan berprestasi.

Disiplin kerja yang tinggi memegang peranan yang sangat penting dalam upaya meningkatkan produktivitas kerja perawat. Disiplin kerja yang tinggi akan mempercepat pencapaian tujuan organisasi dan disiplin kerja yang rendah akan menjadi penghalang dan memperlambat tujuan organisasi (Sedarmayanti, 2011).

Selain kedisiplinan pihak Rumah Sakit Juga harus memperhatikan lingkungan kerja pegawai agar pegawai dapat bekerja secara efektif dan efesien, karena lingkungan kerja dapat mempengaruhi seseorang dalam melaksanakan tugas yang dibebankan baik secara langsung maupun tidak langsung. Manfaat lingkungan kerja adalah menciptakan gairah kerja, sehingga produktivitas dan prestasi kerja meningkat (Jais, 2017).

Rumah sakit di Bandar Lampung yang telah terakreditasi paripurna berdasarkan penilaian Komite Akreditasi Rumah Sakit (KARS) 2012, salah satunya yaitu Rumah Sakit Pertamina Bintang Amin (RSPBA). Persentase kepuasan pasien rawat inap Rumah Sakit Pertamina Bintang Amin (RSPBA) Bandar Lampung yang juga dinilai secara intenal pada tahun 2017, yaitu $75 \%$. Nilai ini juga masih berada di bawah dari indikator Standar Pelayanan Minimal (SPM) rawat inap, yaitu 90\%. Penelitian ini mengambil sampel di RS Pertamina Bintang Amin yang merupakan salah satu RS bertipe C di
Bandar Lampung. RS ini juga menampung pelayanan rujukan dari Fasilitas kesehatan tingkat pertama.

Berdasarkan data yang peneliti dapat dari bagian Humas RS Pertamina Bintang Amin didapatkan, tingkat kepuasan pasien sebesar 75\%, pemanfaatan tempat tidur yaitu BOR rumah sakit yang berfluktuasi dengan nilai rata rata $55 \%$ artinya masih di bawah standar dari nilai normal 60-80 $\%$ menggambarkan mutu efisiensi masih kurang optimal. Indikator pelayanan rumah sakit yaitu Average length of stay (ALOS ) dengan rata rata lama hari rawat nilai standar 6-9 hari dan jauh berbeda dengan perawatan yang ada di Rumah Sakit masih di bawah standar ideal yaitu 3-4 hari. Sedangkan berdasarkan Kepmenkes No 129 tentang standar pelayanan minimal rumah sakit, pada unit rawat inap kepuasan pasien dengan indikator $\geq 90$ $\%$. Hal tersebut dapat menunjukkan bahwa kualitas pelayanan belum mencapai standar SPM atau masih rendah (Rumah Sakit Bintang Amin Bandar Lampung , 2017).

Pada tahun 2014 sampai dengan tahun 2016 masih terdapat beberapa karyawan Rumah Sakit Bintang Amin Bandar Lampung kurang disiplin. Hal ini dapat dilihat dari data absensi dari tahun ketahun terdapat keterlambatan, ijin, sakit dan cuti dan masih terdapat fasilitas rumah sakit yang kotor dan kurang layak. Selain itu masih terdapat karyawan non medis yang bekerja kurang mentaati peraturan saat bekerja dirumah sakit seperti contoh kurang terjaganya kebersihan lingkungan dirumah sakit dan kamar mandi yang kurang bersih. Dan data yang diperoleh bulan Desember 2016 karyawan Rumah Sakit Bintang Amin Bandar Lampung memiliki karyawan sejumlah 434 orang. Dari total tersebut dibagi 141 perawat, 170 bidan, dan sisanya karyawan untuk unit kerja medis seperti Dokter Umum, Dokter Spesialis serta unit kerja non medis karyawan yang meliputi Rekam Medis, Farmasi, Laborat, Gizi, Fisioterapi, Keuangan Kasir, Kantor Umum, Security, IPSRS, Driver, Operator, Laundry, Radiologi, 
Pendorong IGD/PUK dan Tukang kebun. Berdasarkan latar belakang diatas penelitian ini bertujuan mengetahui Faktor - Faktor yang Mempengaruhi Produktivitas Kerja Perawat di Ruang Rawat Inap Rumah Sakit Pertamina Bintang Amin.

\section{METODE}

Jenis penelitian ini merupakan jenis penelitian kuantitatif dengan menggunakan metode survei analitik dan rancangan penelitian yaitu cross sectional. Penelitian ini dilakukan di ruang rawat inap, instalasi gawat darurat dan poliklinik di RSPBA. Penelitian dilakukan pada bulan September 2018. Subjek penelitian adalah 104 perawat di RSPBA baik pegawai tetap maupun pegawai kontrak.

Variabel bebas adalah variabel yang apabila nilainya berubah akan mempengaruhi variabel lain (Arikunto, 2013), dalam penelitian ini, yang menjadi variable bebas adalah disiplin kerja, lingkungan kerja, etos kerja dan kesempatan berprestasi. Variabel terikat adalah variabel yang dipengaruhi oleh variable bebas dalam penelitian ini, yang menjadi variabel terikat adalah produktivitas kerja. Instrument pengumpulan data yang digunakan pada penelitian ini adalah kuesioner. Kuesioner yang digunakan dilakukan uji validitas dan reliabilitas dengan karakteristik responden yang sama. Pengumpulan data dilakukan dari dua sumber data yaitu data primer dan data sekunder. Pada penyusunan penyajian data sebagai hasil yang berarti dan kesimpulan yang baik, diperlukan pengolahan data Pengolahan data meliputi Editing, Coding, Entry, Cleaning.

Analisis data hasil penelitian disajikan secara univariat dan bivariat. Analisis ini digunakan untuk mendiskripsikan semua variabel penelitian dalam bentuk tabel dan grafik untuk memberikan deskripsi variabel independen dan dependen (Hastono, 2016). Analisa bivariat adalah tabel silang antara dua variabel, yaitu variabel independen dan variabel dependen. Analisa ini dilakukan untuk mengetahui kemaknaan hubungan yang digunakan adalah tabel kontingensi $2 \times 2$ dengan menggunakan derajat kepercayaan $95 \%$ dan derajat kesalahan $a=0,05$ (Hastono, 2016).

\section{HASIL}

Hasil penelitian pada tabel 1 menunjukkan bahwa sebagian besar dari responden dengan produktivitas kerja baik sebanyak $82 \quad(78,8 \%)$ responden, disiplin kerja baik sebanyak $59(56,7 \%)$ responden, lingkungan kerja baik sebanyak $78 \quad(75,0 \%)$ responden dan etos kerja baik sebanyak $59(56,7 \%)$ responden.

Berdasarkan tabel 2 diketahui bahwa dari 45 responden disiplin kerja kurang baik, sebanyak 15 (33,3\%) responden memiliki produktivitas kerja kurang baik dan sebanyak $30(66,7 \%)$ responden memiliki produktivitas kerja baik. Dari 59 responden disiplin bekerja baik, sebanyak 7 (11,9\%) responden memiliki produktivitas kerja kurang baik dan sebanyak $52(88,1 \%)$ responden memiliki produktivitas kerja baik. Hasil uji statistik diperoleh $p$-value $=0,016$ yang berarti $\mathrm{p}<\mathrm{a}=0,05$ ( $\mathrm{HO}$ ditolak dan Ha diterima), maka dapat disimpulkan bahwa ada hubungan disiplin kerja dengan produktivitas kerja perawat di Ruang Rawat Inap RS Pertamina Bintang Amin Bandar Lampung Tahun 2018. Dengan nilai OR 3,714 berarti responden disiplin kerja baik memiliki peluang 3,7 kali lebih besar produktivitas kerja baik jika dibandingkan dengan responden disiplin kerja kurang baik.

Berdasarkan tabel 3 diketahui bahwa dari 26 responden lingkungan kerja kurang baik, sebanyak 13 $(50,0 \%)$ responden memiliki produktivitas kerja kurang baik dan sebanyak $13 \quad(50,0 \%)$ responden memiliki produktivitas kerja baik. Dari 78 responden lingkungan kerja baik, sebanyak $9(11,5 \%)$ responden memiliki produktivitas kerja kurang baik dan sebanyak $69 \quad(88,5 \%)$ responden memiliki produktivitas kerja baik. Hasil uji statistik diperoleh $p$-value $=0,000$ yang berarti $p>a=0,05$ (H0 ditolak dan 
Ha diterima), maka dapat disimpulkan bahwa ada hubungan lingkungan kerja dengan produktivitas kerja perawat di Ruang Rawat Inap RS Pertamina Bintang Amin Bandar Lampung Tahun 2018. Dengan nilai OR 7,667 berarti responden lingkungan kerja baik memiliki peluang 7,6 kali lebih besar produktivitas kerja baik jika dibandingkan dengan responden lingkungan kerja kurang baik.

Tabel 1. Distribusi Frekuensi Faktor - Faktor (Disiplin Kerja, Lingkungan Kerja, Etos Kerja dan Kesempatan Berprestasi) Dengan Produktivitas Kerja Perawat Di Ruang Rawat Inap RS Pertamina Bintang Amin Bandar Lampung Tahun 2018

\begin{tabular}{lccc}
\hline \multicolumn{1}{c}{ Variabel } & Kategori & Frekuensi & Persentase (\%) \\
\hline Produktivitas kerja & Kurang & 22 & 21.2 \\
\cline { 2 - 4 } & Baik & 82 & 78.8 \\
\hline Disiplin kerja & Kurang & 45 & 43.3 \\
\cline { 2 - 4 } & Baik & 59 & 56.7 \\
\hline \multirow{2}{*}{ Lingkungan kerja } & Kurang & 26 & 25.0 \\
\cline { 2 - 4 } & Baik & 78 & 75.0 \\
\hline Etos kerja & Kurang & 45 & 43.3 \\
\cline { 2 - 4 } & Baik & 59 & 56.7 \\
\hline Total & & 104 & 100,0 \\
\hline
\end{tabular}

Tabel 2. Hubungan Disiplin Kerja Dengan Produktivitas Kerja Perawat Di Ruang Rawat Inap RS Pertamina Bintang Amin Bandar Lampung Tahun 2018

\begin{tabular}{|c|c|c|c|c|c|c|c|c|}
\hline \multirow{3}{*}{ Disiplin kerja } & \multicolumn{4}{|c|}{ Produktivitas kerja } & \multicolumn{2}{|c|}{ Total } & \multirow[t]{3}{*}{$\begin{array}{c}p- \\
\text { value }\end{array}$} & \multirow[t]{3}{*}{$\begin{array}{c}\text { OR } \\
95 \% \mathrm{CI}\end{array}$} \\
\hline & \multicolumn{2}{|c|}{ Kurang } & \multicolumn{2}{|c|}{ Baik } & & & & \\
\hline & $\mathbf{n}$ & $\%$ & $\mathbf{n}$ & $\%$ & $\mathbf{N}$ & $\%$ & & \\
\hline Kurang & 15 & 33,3 & 30 & 66,7 & 45 & 100 & & 3,714 \\
\hline Baik & 7 & 11,9 & 52 & 88,1 & 59 & 100 & 0,016 & $\begin{array}{l}(1,362- \\
10,131)\end{array}$ \\
\hline
\end{tabular}

Tabel 3. Hubungan Lingkungan Kerja Dengan Produktivitas Kerja Perawat Di Ruang Rawat Inap RS Pertamina Bintang Amin Bandar Lampung Tahun 2018

\begin{tabular}{|c|c|c|c|c|c|c|c|c|}
\hline \multirow{3}{*}{$\begin{array}{l}\text { Lingkungan } \\
\text { kerja }\end{array}$} & \multicolumn{4}{|c|}{ Produktivitas kerja } & \multirow{2}{*}{\multicolumn{2}{|c|}{ Total }} & \multirow{3}{*}{$\begin{array}{c}p- \\
\text { value }\end{array}$} & \multirow{3}{*}{ OR 95\%CI } \\
\hline & \multicolumn{2}{|c|}{ Kurang } & \multicolumn{2}{|c|}{ Baik } & & & & \\
\hline & $\mathbf{n}$ & $\%$ & $n$ & $\%$ & $\mathbf{N}$ & $\%$ & & \\
\hline Kurang & 13 & 50,0 & 13 & 50,0 & 26 & 100 & & 7,667 \\
\hline Baik & 9 & 11,5 & 69 & 88,5 & 78 & 100 & 0,000 & $\begin{array}{l}(2,720- \\
21,606)\end{array}$ \\
\hline
\end{tabular}

Berdasarkan tabel 4 diketahui bahwa dari 45 responden etos kerja kurang, yaitu sebanyak $16(35,6 \%)$ responden memiliki produktivias kerja kurang dan sebanyak $29 \quad(64,4 \%)$ responden memiliki produktivitas kerja baik. Dari 59 responden etos kerja baik, sebanyak $6 \quad(10,2 \%)$ 
responden memiliki produktivitas kerja kurang dan sebanyak 53 $(89,8 \%)$ responden memiliki produktivitas kerja baik. Hasil uji statistik diperoleh $p$-value $=0,004$ yang berarti $p>a=0,05$ (HO ditolak dan $\mathrm{Ha}$ diterima), maka dapat disimpulkan bahwa ada hubungan etos kerja dengan produktivitas kerja perawat di Ruang Rawat Inap RS Pertamina Bintang Amin Bandar Lampung Tahun 2018. Dengan nilai OR 4,874 berarti responden etos kerja baik memiliki peluang 4,8 kali lebih besar

memiliki produktivitas kerja baik jika dibandingkan dengan responden etos kerja kurang baik.

Tabel 4. Hubungan Etos Kerja Dengan Produktivitas Kerja Perawat di Ruang Rawat Inaprs Pertamina Bintang Amin Bandar Lampung Tahun 2018

\begin{tabular}{|c|c|c|c|c|c|c|c|c|}
\hline \multirow{3}{*}{$\begin{array}{l}\text { Etos } \\
\text { kerja }\end{array}$} & \multicolumn{4}{|c|}{ Produktivitas kerja } & \multirow{2}{*}{\multicolumn{2}{|c|}{ Total }} & \multirow{3}{*}{$\begin{array}{c}p- \\
\text { value }\end{array}$} & \multirow{3}{*}{$\begin{array}{c}\text { OR } \\
95 \% \mathrm{CI}\end{array}$} \\
\hline & \multicolumn{2}{|c|}{ Kurang } & \multicolumn{2}{|c|}{ Baik } & & & & \\
\hline & $\mathbf{n}$ & $\%$ & $\mathbf{n}$ & $\%$ & $\mathbf{n}$ & $\%$ & & \\
\hline Kurang & 16 & 35,6 & 29 & 64,4 & 45 & 100 & & 4,874 \\
\hline Baik & 6 & 10,2 & 53 & 89,8 & 59 & 100 & 0,004 & $(1,720-$ \\
\hline
\end{tabular}

\section{PEMBAHASAN}

Berdasarkan

teori

yang

dikemukakan oleh Sedarmayanti (2011)

pentingnya produktivitas dalam

meningkatkan kesejahteraan telah

disadari secara universal, tidak ada

jenis kegiatan manusia yang tidak

mendapatkan keuntungan dari

produktivitas yang ditingkatkan sebagai

kekuatan untuk menhasilkan lebih

banyak barang maupun jasa.

Peningkatan produktivitas juga

menghasilkan peningkatan langsung

pada standar hidup yang berada di

bawah konsidi distribusi yang sama dan

perolehan produktivitas yang sesuai

dengan masukan tenaga kerja.

Meningkatkan produktivitas berarti

bekerja lebih giat dan cepat, meningkatkan mutu barang, kerja dan kehidupan.

Untuk

meningkatkan

penumbuhan ekonomi, upah yang wajar dan untuk meningkatkan kondisi kerja, perlu mempertimbangkan produktivitas sebagai faktor penyumbang terbesar. Karena menusia adalah sumber daya yang penting dan merupakan tujuan dari bukan atas beban biaya mereka tetapi atas beban biaya dari waktu yang terbuang, pengurangan pegawai, birokrasi yang tidak perlu dan sebagainya. Penelitian yang dilakukan oleh Fajariadi (2014) analisis etos kerja, iklim kerja dan disiplin kerja terhadap produktivitas kerja perawat pelaksana di rumah sakit jiwa provinsi sumatera utara. Hasil proporsi responden pada aspek produktivitas kerjanya memperlihatkan produktivitas kerja baik sebanyak 49 responden $(81,7 \%)$ responden dan memperlihatkan produktivitas kerja kurang baik sebanyak 11 responden $(18,3 \%)$.

Penelitian yang dilakukan oleh Fajariadi (2014) terdapat hubungan yang signifikan antara disiplin kerja dengan produktivitas kerja perawat pelaksana di Rumah Sakit Jiwa Provinsi Sumatera Utara. Penelitian serupa yang dilakukan oleh Asbakhul'ulum (2010), di ketahui bahwa hasil korelasi antara disiplin kerja dengan produktivitas kerja karyawan menunjukan nilai hitung $r$ 0.846 dan nilai tabel $r$ adalah 0.000 . Artinya semakin tinggi tingkat disiplin kerja maka semakin tinggi pula produktivitas kerja karyawan dan sebaliknya jika semakin rendah disiplin kerja maka semakin rendah pula produktivitas kerja karyawan. Penelitian lain oleh Trianto dan Toto (2010) memperkuat pernyataan bahwa disiplin kerja baik secara parsial maupun secara bersama-sama 
berpengaruh terhadap produktivitas kerja karyawan. Faslah (2013) dalam penelitiannya juga menyatakan bahwa untuk menciptakan produktivitas kerja karyawan tidak mudah, banyak faktor mempengaruhinya diantaranya disiplin kerja karyawan pada perusahaan.

Menurut Mangkunegara (2014) manfaat lingkungan kerja adalah menciptakan gairah kerja sehingga produktivitas kerja meningkat. Sementara itu, manfaat yang diperoleh karena bekerja dengan orang yang termotivasi adalah pekerjaan dapat diselesaikan dengan tepat. Artinya pekerjaan diselesaikan sesuai standar yang benar dan dalam skala waktu yang ditentukan. Kinerjanya akan dipantau oleh individu yang bersangkutan, dan tidak akan membutuhkan terlalu banyak pengawasan serta semangat juangnya akan tinggi. Penelitian Susanti (2014) berdasarkan hasil penelitian menyatakan bahwa ada hubungan antara lingkungan kerja dengan produktivitas kerja perawat pelaksana di ruang rawat inap RSUD Cibinong tahun 2014.

Berdasarkan hasil penelitian diketahui bahwa dari 26 responden lingkungan kerja kurang baik, sebanyak $13(50,0 \%)$ responden memiliki produktivitas kerja kurang baik menurut pendapat peneliti lingkungan kerja merupakan segala sesuatu yang ada disekitar perawat yang dapat memengaruhi dirinya dalam menjalankan tugas-tugas yang sudah diembankan padanya. Lingkungan kerja sangat berpengaruh terhadap semangat kerja dimana perawat tidak mungkin dapat melakukan pekerjaan sebagaimana yang diharapkan tanpa ditunjang lingkungan kerja yang mendukung kenyamanan perawat di dalam melaksanakan pekerjaan seharihari dan sebanyak 13 (50,0\%) responden memiliki produktivitas kerja baik. Dari 78 responden lingkungan kerja baik, sebanyak 9 (11,5\%) responden memiliki produktivitas kerja kurang baik dan sebanyak $69(88,5 \%)$ responden memiliki produktivitas kerja baik menurut pendapat peneliti kualitas kehidupan kerja atau QWL (Quality of
Work Life) diperlukan dalam lingkungan kerja di rumah sakit. Melalui pendekatan manajemen sumber daya manusia harus mampu menciptakan kualitas kehidupan kerja QWL yang dapat memberi kesempatan pengembangan diri, kesejahteraan yang dapat menutupi kebutuhan dasar pekerja, serta lingkungan kerja yang aman dan nyaman sehingga dapat membangkitkan semangat kerja dalam upaya pencapaian tujuan secara lebih baik. Setiap orang dapat mengembangkan potensi yang ada dalam dirinya, dengan diberikan kesempatan berprestasi, maka karyawan akan meningkatkan produktivitas.

Etos kerja tercermin dalam kedisiplinan melaksanakan pekerjaan. Perawat juga dituntut untuk disiplin dalam bekerja. Menurut Tulus (2004), menyatakan masalah kedisiplinan kerja merupakan masalah yang perlu diperhatikan, sebab dengan adanya kedisiplinan, dapat mempengaruhi efektivitas dan efisiensi dalam pencapaian tujuan organisasi (Hasibuan, 2011). Kecenderungan penurunan produktivitas perusahaan salah satunya diakibatkan oleh perilaku kerja para karyawan yang kurang disiplin, yang ditunjukan oleh perilaku karyawan yang sering bolos, tertidur saat jam kerja sedang aktif, atau pulang lebih awal dari jam kerja. Dengan sering tidak disiplinya SDM maka target penyelesaian pekerjaan tidak pernah tercapai yang pada gilirannya berpengaruh terhadap produktivitas kerja organisasi (Ilyas, 2012).

Penelitian yang dilakukan oleh Fajariadi (2014) analisis etos kerja, terhadap produktivitas kerja perawat pelaksana di rumah sakit jiwa provinsi sumatera utara. Terdapat hubungan antara etos kerja dengan produktivitas kerja perawat pelaksana di Rumah Sakit Jiwa Provinsi Sumatera Utara.

Berdasarkan hasil penelitian diketahui bahwa dari 45 responden etos kerja kurang baik sebanyak 16 $(35,6 \%)$ responden memiliki produktivitas kerja kurang menurut pendapat peneliti persaingan antar 
rumah sakit baik pemerintah, swasta dan asing akan semakin keras untuk merebut pasar yang semakin terbuka bebas. Merencanakan kebutuhan SDM secara tepat sesuai dengan fungsi pelayanan setiap unit, bagian dan instalasi rumah sakit menjadi upaya penting untuk menghadapi tantangan rumah sakit di masa sekarang dan mendatang.Ketepatan dalam pemilihan, penerimaan, pengelolaan, dan pengembangan SDM rumah sakit merupakan kunci sukses rumah sakit untuk berkembang di masa depan dalam hal ini SDM yang memiliki etos kerja yang kurang baik dapat berpengaruh terhadap produktivitas yang di hasilkan atau di tampilkan oleh rumah sakit seperti pelayanan kepada pasien yang kurang baik sehingga dapat mempengaruhi kepuasan pasien selama dirawat di rumah sakit dan sebanyak 29 $(64,4 \%)$ responden memiliki produktivitas kerja baik hal ini dikarenakan adanya faktor lain sehingga walaupun etos kerja yang ditampilkan kurang baik namun masih ada faktor lain sehingga produktivitas perawat tersebut masih dalam kategori baik.

Berdasarkan hasil penelitian juga terlihat bahwa dari 59 responden etos kerja baik, sebanyak $6 \quad(10,2 \%)$ responden memiliki produktivitas kerja kurang hal ini dikarenakan adanya faktor lain yang mempengaruhi produktivitas kerja sehingga walaupun perawat memiliki etos kerja yang baik namun karena adanya faktor lain sehingga produktivitas yang ditampilkan menjadi kurang baik. Menurut pendapat peneliti etos kerja dalam penelitian ini adalah persepsi perawat mengenai seperangkat perilaku kerja yang etis yang lahir sebagai buah keyakinan fundamental sebagai panduan tingkah laku bagi perawat dalam melaksanakan asuhan keperawatan yang bermutu dengan indikator kerja adalah rahmat, kerja adalah amanah, kerja adalah aktualisasi, kerja itu ibadah. Peningkatan etos kerja dalam organisasi merupakan tugas dan tanggung jawab semua lapisan, terutama pimpinan dalam membina serta membimbing bawahannya supaya dapat bekerja dengan baik dan benar sesuai dengan tugas dan fungsinya masing-masing. Dengan etos kerja yang baik maka akan tercipta suasana kerja yang kondusif yang akan mendukung pelaksanaan tugas yang baik dan memberikan tingkat produktivitas yang tinggi.

\section{KESIMPULAN}

Produktivitas kerja karyawan merupakan faktor yang sangat penting dalam menunjang keberhasilan usaha. Produktivitas juga mencerminkan etos kerja karyawan yang tercermin juga sikap mental yang baik. Pelayanan keperawatan yang ada di ruangan rawat inap merupakan salah satu tolak ukur di rumah sakit. Ada hubungan antara disiplin kerja, lingkungan kerja dan etos kerja dengan produktivitas kerja perawat di Ruang Rawat Inap Rumah Sakit Pertamina Bintang Amin Tahun 2018.

Adanya standar kerja yang baku maka kepastian kerja akan menjadi jelas, masing-masing akan mengetahui batas kewenangan dan tanggungjawabnya, sehingga memperlancar pekerjaan sehari-hari secara baik yang akhirnya akan meningkatkan produktivitasnya. Menumbuhkan pemahaman terhadap etika profesi, membangkitka kesadaran dan membuka pandangan serta sikap kepada para perawat untuk menilai tinggi terhadap kerja keras dan sungguh-sungguh, dan mengikis sikap kerja yang asal-asalan yang tidak berorientasi terhadap mutu.

\section{DAFTAR PUSTAKA}

Arikunto, Suharsimi. (2013). Prosedur Penelitian: Suatu Pendekatan Praktik. Jakarta: Rineka Cipta.

Asbakhul'ulum, M. (2010). Hubungan Disiplin Kerja Dengan Produktivitas Kerja Karyawan Di Perusahaan Daerah Air Minum (PDAM) Kota Blitar. Skripsi Tidak Dipublikasikan Fakultas Psikologi Universitas Islam NegeriMaulana Malik Ibrahim Malang 
Fajariadi, D., (2014). Analisis Etos Kerja, Iklim kerja dan Disiplin kerja Terhadap Produktivitas Kerja Perawat Pelaksana di Rumah Sakit Jiwa Provinsi Sumatera Utara. Universitas Sumatera Utara, Medan.

Faslah, R., \& Savitri, M. T. (2013). Pengaruh Motivasi Kerja Dan Disiplin Kerja Terhadap Produktivitas Kerja Pada Karyawan Pt. Kabelindo MurnI, Tbk. Jurnal Pendidikan Ekonomi dan Bisnis.

Hasibuan, H. Malayu SP (2011). Manajemen Sumber Daya Manusia. Bumi Aksara. Jakarta

Hastono, S. P. (2016). Analisis data pada bidang kesehatan. Jakarta: RajaGrafindo Persada.

Ilyas, Yaslis. (2012). Kiat sukses manajemen tim kerja. Gramedia Pustaka Utama.

Jais, A. (2017). Pengaruh Disiplin Kerja dan lingkungan kerja Terhadap prestasi kerja Pegawai pada Rumah Sakit Umum Daerah $H$. Andi Sulthan Daeng Radja Kabupaten Bulukumba (Doctoral dissertation, Univeritas Islam Negeri Alauddin Makassar).

Kementerian Kesehatan RI, (2016). Profil Kesehatan Indonesia 2015, Kemenkes RI, Jakarta.

Mangkunegara, A.A.P. (2013). Manajemen Sumber Daya Manusia dan Perusahaan. Bandung. Perusahaan Rosda.

Profil Kesehatan Rumah Sakit Bintang Amin. (2017). Profil Kesehatan Rumah Sakit Bintang Amin Tahun 2017. Bandar Lampung.

Sedarmayanti, (2011), Tata Kerja dan Produktivitas Kerja. Penerbit Mandar Maju, Bandung.

Susanti, F. A. (2014). Faktor-Faktor Yang Berhubungan Dengan Produktivitas Kerja Perawat Pelaksana Di Ruang Rawat Inap RSUD Cibinong Tahun 2014.

Trianto, A., \& Toto, S. (2010). Effect of Compensation, Discipline, And
Work Motivation On Employee Productivity Of PT Kukdong International. Journal Faculty Of Economics Gunadarma.

Tulus, Tu'u. (2004). Peran disiplin pada perilaku dan prestasi belajar. Jakarta: Grasind 